\title{
GEOGRAPHIC TONGUE WITH BURNING MOUTH SYNDROME (CASE REPORT)
}

\author{
Nendika Dyah Ayu Murika Sari*, Rochman Mujayanto*
}

${ }^{*}$ Fakultas Kedokteran Gigi, Universitas Muhammadiyah Surakarta

${ }^{*}$ Departemen IImu Penyakit Mulut, Fakultas Kedokteran Gigi, Universitas Islam Sultan Agung, Semarang

Correspondence: nendika.dyahayu@ums.ac.id

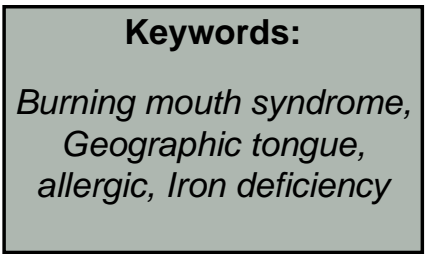

\section{PENDAHULUAN}

Geographic tongue adalah suatu kondisi yang melibatkan permukaan dorsal lidah dengan area yang terlihat depapila. Warna bisa tampak putih kekuningan atau dapat juga keabu-abuan dengan batas yang terkadang tidak jelas. Lesi ini berbentuk seperti pulaupulau dan dapat dengan cepat berpindahpindah sehingga sering disebut dengan benign migratory glossitis. Secara histopatologis terlihat hilangnya papila filiformis, adanya hiperplasia epitel psoriasiform dengan spongiosis pustula spongiotik yang melibatkan sepertiga hingga dua pertiga dari ketebalan epitel serta adanya gambaran infiltrat variabel limfositik. ${ }^{(1-3)}$

Kondisi ini biasanya tanpa gejala, namun ada beberapa yang mengeluhkan adanya rasa yang tidak nyaman saat makan-makanan pedas dan asam. Tingkat rasa tidak nyaman bermacam-macam tergantung dari lesinya dan juga dirasakan pada waktu yang berbeda-beda. Rasa tidak nyaman yang parah dapat ditandai dengan sensasi rasa terbakar pada permukaan mukosa oral dan anterior lidah yang biasa dikenal dengan burning mouth syndrome (BMS). ${ }^{(1,2,4-6)}$ Prevalensi BMS sekitar 0,7\% hingga $5 \%$ dari total populasi. Selain disertai dengan BMS, geographic tongue dapat disertai 
dengan adanya fissure tongue. Dari prevalensi $1-2 \%$ populasi orang dewasa yang mengalami geographic tongue, seperempat atau $25 \%$ nya disertai dengan fissure tongue. ${ }^{(5,7,8)}$

Etiologi dan patogenesis dari geographic tongue belum diketahui secara pasti. Dalam beberapa penelitian, geographic tongue disebut sebagai manifestasi klinis dari atopi. Faktor penyebab lain yang sering dihubungkan dengan kondisi ini adalah psoriasis, gangguan hormonal, alergi, diabetes pada saat usia remaja, sindrom Down, sindrom Reiter, gangguan psikologis dan defisiensi nutrisi. Beberapa faktor yang dihubungkan dengan terjadinya geographic tongue tersebut dinilai mampu menyebabkan BMS seperti perubahan hormonal, defisiensi nutrisi dan alergi. Selain kedua faktor tersebut, BSM juga berhubungan dengan xerostomia, kandidiasi, diabetes dan kondisi sistemik lainnya. Faktor keturunan dan faktor lingkungan juga pernah dilaporkan sebagai geographic tongue..$^{(1,9,10)}$ Studi yang dilakukan oleh Amal mengatakan jika obatobatan yang digunakan dalam pengobatan hipertensi dalam menjadi penyebab munculnya geographic tongue.(11) Penulisan ini bertujuan untuk melaporkan kondisi geographic tongue yang disertai dengan burning mouth syndrome (BSM).

\section{LAPORAN KASUS}

Wanita berusia 23 tahun datang ke RSIGM Sultan Agung Semarang dengan keluhan lidah pecah-pecah yang dirasakan sejak kecil dan belum pernah diperiksakan ke dokter gigi. Pasien juga mengeluh pada bagian tengah lidah ada bercak putih yang berpindah-pindah, bercak tidak pernah sakit dan pernah disikat namun tidak hilang. Pasien sering merasakan perih terutama saat makan makanan yang pedas dan satu bulan terakhir rasa perih semakin meningkat. Pasien mengaku alergi terhadap berbagai jenis makanan seperti seafood, daging, ayam dan telur. Pasien lebih sering makan tempe tahu dan mie instan. Dari pemeriksaan fisik dan pemeriksaan ekstra oral dalam batas normal. Hasil pemeriksaan intra oral didapatkan adanya fisura multiple pada dorsum dan lateral lingual serta bercak putih kekuningan multiple sepanjang $10 \mathrm{~mm}$ pada dorsum lingual.

Kunjungan pertama pada tanggal 19 Oktober 2015 dilakukan pemeriksaan subjektif dan objektif dengan diagnosis fissure tongue dan geographic tongue. Kemudian pasien dilakukan edukasi serta pemberian obat kumur dengan instruksi pemakaian 2 kali sehari selama 1 minggu. Kunjungan selanjutnya setelah pemakaian obat kumur adalah pada tanggal 28 oktober 2015. Pemeriksaan subjektif, pasien masih mengeluh perih dan perih semakin hebat sejak 2 hari yang lalu. Setelah dilakukan pemeriksaan objektif, untuk menegakkan diagnosis pasien dirujuk ke laboratorium klinik untuk pemeriksaan darah lengkap dan lgE total serta ke laboratorium mikrobiologi untuk pemeriksaan $\mathrm{KOH}$ (pemeriksaan mikroskopis dengan larutan kalium hidroksida $10 \%$ untuk pemeriksaan jamur yang akan terlihat hifa dan spora) dan identifikasi jamur. Diagnosis sementara adalah candidiasis dengan differential diagnosis glositis. Pemakaian obat kumur tetap dilanjutkan.

Kunjungan ketiga pada tanggal 16 November 2015, pemeriksaan subjektif masih dikeluhkan rasa perih. Rasa perih bukan hanya saat makan pedas tetapi sesudah makan juga masih perih. Rasa perih dirasakan lebih hebat semenjak menggunakan obat kumur 
dibandingkan sebelum menggunakan obat kumur. Hasil pemeriksaan penunjang adalah sebagai berikut :

a. Pemeriksaan darah lengkap : nilai RBC (Red Blood Cell count untuk menghitung jumlah total sel darah merah) adalah 5.81 (lebih dari normal), MCV (Mean Corpuscular Volume untuk mengetahui volume rata-rata eritrosit) adalah 70.1 (kurang dari normal), $\mathrm{MCH}$ (Mean Corpuscular Hemoglobin untuk mengetahui jumlah hemoglobin dalam eritrosit) adalah 23.6 (kurang dari normal) dan PLT (platelet) adalah 462 (lebih dari normal).

b. Pemeriksaan mikrobiologi : tidak ditemukan jamur dan tidak terdapat pertumbuhan jamur.

c. Pemeriksaan IgE total 118.3 (lebih dari normal)

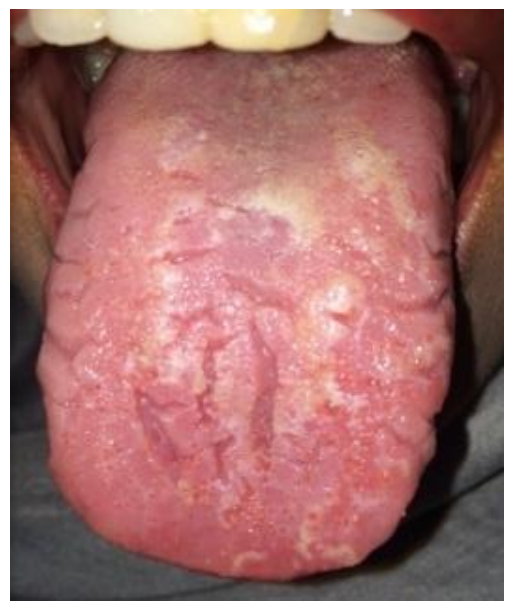

(a)
Diagnosis setelah dilakukan pemeriksaan penunjang adalah geographic tongue disertai burning mouth syndrome et causa reaksi alergi dan defisiensi zat besi. Penatalaksanaan untuk kasus ini yaitu melakukan komunikasi informasi dan edukasi (KIE) serta medikasi. Edukasi yang disampaikan antara lain untuk tidak makan makanan yang pedas, konsultasi ke dokter spesialis kulit dan dokter spesialis penyakit dalam. Medikasi yang diberikan yaitu vitamin yang mengandung zat besi (Ferrous Sulphate $200 \mathrm{mg}$, sehari 2 kali).

\section{Kunjungan keempat pada tanggal 7} Desember 2015, pasien datang untuk kontrol. Dari hasil anamnesis didapatkan jika keluhan sudah berkurang. Pasien minum vitamin yang diberikan secara rutin serta saat makan panas dan pedas sudah tidak terlalu nyeri. Pasien tetap diedukasi untuk melanjutkan vitamin hingga habis dan dianjurkan untuk ke segera ke dokter spesialis penyakit dalam dan dokter spesialis penyakit kulit.

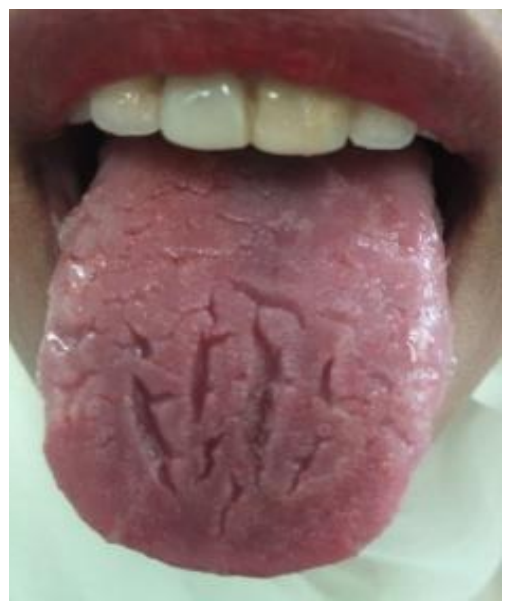

(b) 


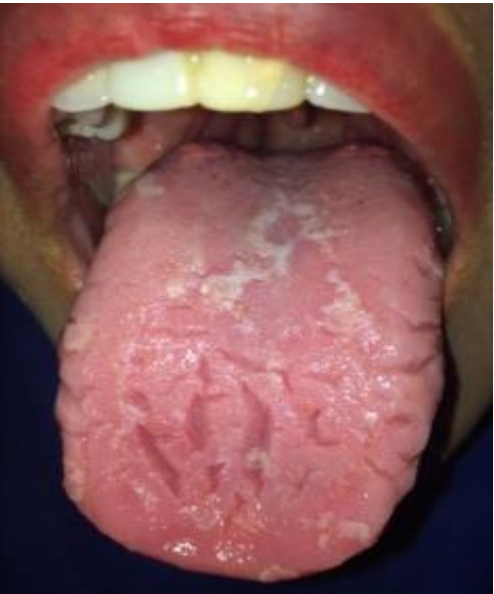

(c)

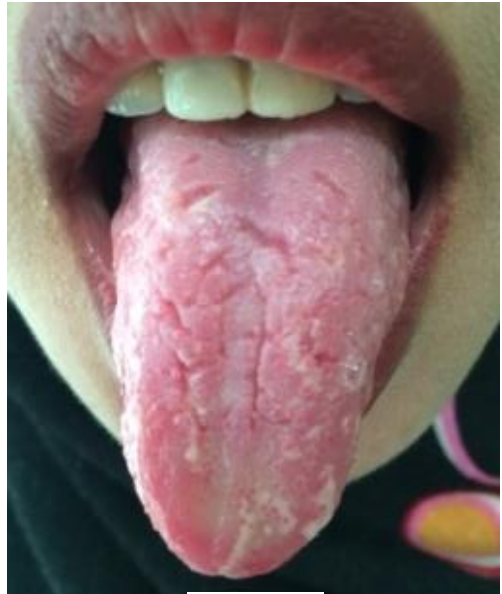

(d)

Gambar 1. (a) Kunjungan pertama (b) Kunjungan kedua (c) Kunjungan ketiga (d) Kunjungan keempat

\section{DISKUSI}

Geographic tongue sering tidak disadari keberadaannya oleh penderita karena lesi ini sering muncul tanpa diikuti dengan gejala apapun. Geographic tongue hingga saat ini masih belum diketahui etiopatogenesis secara pasti. ${ }^{(7-9,11,12)}$ Secara umum, patogenesis geographic tongue dihubungkan dengan pergantian epitel dimana terdapat proses deskuamasi dan keratinisasi. Normalnya laju deskuamasi sel epitel sama dengan laju pergantingan sel oleh lapisan basal epitel mukosa mulut. Dalam hal ini diperkirakan tingkat deskuamasi epitel terjadi lebih cepat sehingga pematangan keratin menurun. Geographic tongue dianggap memiliki kecacatan dalam mekanisme yang mengontrol deskuamasi sel epitel, regenerasi dan keratinisasi.(11)

Geographic tongue dalam beberapa penelitian ditemukan pada pasien alergi. Menurut salah satu peneliti, geographic tongue adalah pola reaksi lidah terhadap kondisi yang mendasarinya yaitu alergi. Pasien dengan geographic tongue menunjukkan peningkatan kadar IgE dalam serum yang merupakan tanda atopi atau alergi. Kondisi ini dapat disertai dengan sensitivitas pada lidah yang secara klinis tampak sebagai glositis papiler fungiformis.(11) Geographic tongue dimediasi secara imunologi dan inflamasi kronis, namun patogenesis secara pasti belum diketahui. Geographic tongue juga umum terjadi pada kondisi inflamasi akut yang berulang pada permukaan yang bersentuhan dengan lingkungan luar.(13-15) Kondisi tersebut sama seperti kasus yang ditemukan yaitu adanya peningkatan IgE total.

Prevalensi terjadinya geographic tongue pada pasien yang memiliki alergi sekitar 35,7\% hingga $40,5 \%$. $^{(16)}$ Alergi sangat umum terjadi pada berbagai populasi. Alergi berhubungan dengan kepekaan terhadap alergen yang ada dilingkungan seperti serbuk sari, makanan, jamur, serangga dan juga obat-obatan. Alergi terutama alergi makanan dihubungkan dengan defisiensi nutrisi.(11,17) Pada kasus tersebut, pasien mempunyai alergi pada berbagai jenis makanan, hal ini membuat pasien hanya makan-makanan tertentu.

Defisiensi nutrisi akibat alergi makanan bisa beragam. Dari hasil pemeriksaan darah lengkap, pasien ini memiliki nilai $\mathrm{MCH}$ dan MCV kurang dari normal. Kondisi ini dihubungkan 
dengan defisiensi zat besi. Kekurangan zat besi merupakan penyebab paling sering pada anemia atau biasa diindikasikan dengan konsentrasi hemoglobin dibawah ambang batas. Defisiensi zat besi dapat juga terjadi tanpa adanya anemia. Sama seperti alergi, kekurangan zat besi juga sering dihubungkan dengan adanya geographic tongue.(18,19) Patogenesis secara pasti juga belum diketahui, namun sering dihubungan dengan glositis yang mengalami atrofi papiler. Jenis glositis ini yang sering disalahartikan sebagai geographic tongue. ${ }^{(11)}$

Geographic tongue dalam beberapa kasus muncul bersama dengan adanya fissure tongue. Orang akan lebih mudah mengenali adanya fisura di lidahnya dan datang dengan keluhan adanya lidah yang berfisur. Geographic tongue pada pasien tersebut juga diikuti dengan fissure tongue. Fissure tongue biasanya tidak bergejala yang ditandai dengan adanya celah-celah pada dursum lidah. Dalam beberapa literatur, fissure tongue dinilai menjadi tahap akhir dari geographic tongue. Prevalensi munculnya fissure tongue pada pasien dengan geographic tongue mencapai $50 \% .^{(5,7,18,19)}$ Keluhan lain yang bisa membuat seseorang tersadar jika ada yang berbeda di lidahnya adalah adanya keluhan perih ketika digunakan untuk makan-makanan yang pedas, asam ataupun panas. Rasa perih tersebut mempunyai intensitas yang berbeda hingga dapat juga muncul seperti adanya sensasi terbakar atau biasa dikenal dengan burning mouth syndrome (BMS). ${ }^{(1,4,12)}$

Burning mouth syndrome (BMS) yang ditemukan pada pasien dengan geographic tongue pertama kali dilaporkan pada tahun 1998. Kondisi ini diakibatkan karena adanya perubahan jaringa lokal. Inflamasi yang terjadi pada geographic tongue dapat terangsang terjadi neuropati yang menyebabkan cedera pada indra perasa dan perubahan sensasi. Studi histologis menunjukkan bahwa pada BMS terdapat perubahan syaraf perifer di lidah dengan geographic tongue. Hubungan kedua kondisi ini masih belum diketahui secara pasti, apakah BMS merupakan akibat dari geographic tongue atau keduanya muncul secara bersama-sama. Beberapa penelitian sulit menemukan jawaban, hal itu disebabkan karena sebagian besar pasien tidak menyadari kapan pertama kali muncul geographic tongue yang sering kali tidak disertai dengan rasa sakit. ${ }^{(5,11)}$ Kondisi tersebut sama seperti kasus ini, pasien tidak menyadari adanya geographic tongue dan baru diperiksakan ketika ada kondisi tidak nyaman.

Burning mouth syndrome (BMS) dapat dipengaruhi oleh faktor lokal dan faktor sistemik. Faktor lokal tersebut seperti xerostomia, infeksi, stomatitis, ulkus traumatikus, kebiasaan buruk, gastritis, geographic tongue dan alergi. Sedangkan faktor sistemik seperti diabetes, menopause, Sjogren's syndrome dan defisiensi nutrisi yang meliputi defisiensi vitamin B1, B2, B12, asam folat, zat besi dan zinc. ${ }^{(20)}$ Kekurangan zat besi dapat menyebabkan ketidaknyamanan dalam rongga mulut dengan BMS. Perubahan atrofi pada epitel dari mukosa mulut dapat menyebabkan adanya rasa nyeri. Lidah menunjukkan berbagai tingkat atrofi papiler yang berkelanjutan hingga permukaan lidah halus dan mengkilat, hal tersebut diperkirakan menjadi salah satu penyebab munculnya sensasi rasa terbakar pada kasus defisiensi zat besi.(21) Dalam kasus ini ada tiga faktor yang relevan dengan kondisi pasien yaitu geographic tongue, alergi dan defisiensi zat besi. 
Perawatan untuk geographic tongue biasanya hanya berdasarkan keluhan yang dirasakan pada pasien. Pemberian obat kumur untuk pasien geographic tongue yang disertai dengan fissure tongue dinilai perlu untuk menjaga kebersihan mulut terutama sisa makanan yang bisa menempel pada lidah dan masuk ke fissure.(7,22-24) Pada pasien dengan alergi dapat diberikan antihistamin, namun pada kasus ini tidak diberikan antihistamin karena pasien elergi terhadap makanan sehingga pasien hanya diedukasi untuk menghindari makanan yang dapat menyebabkan alergi. Selain itu, karena pasien mempunyai keluhan perih dan adanya sensasi terbakar saat makan makanan pedas dan panas maka pasien diedukasi untuk menghindari makan makanan pedas dan panas.

Terapi vitamin atau suplemen tambahan juga dapat diberikan sebagai terapi suportif. Terapi asam vitamin A mampu memberi perbaikan pada beberapa pasien. ${ }^{(14,18)}$ Seperti pada kasus ini, suplemen zat besi diberikan setelah didapatkan hasil pemeriksaan darah lengkap. Pemberian suplemen zat besi mampu mengurangi keluhan yang dirasakan pasien yaitu sensasi terbakar. Konsumsi suplemen kurang tepat apabila dikonsumsi dalam jangka waktu lama. Edukasi yang berhubungan dengan tindak lanjut seperti perlu pemeriksaan $\operatorname{lgE}$ spesifik serta terapi lebih lanjut untuk kondisi defisiensi zat besi, maka pasien dianjurkan untuk dapat berkonsultasi dengan dokter spesialis penyakit dalam.

\section{KESIMPULAN}

\section{Geographic tongue dapat disertai dengan burning mouth syndrome (BMS).} Kedua kondisi ini juga berhubungan dengan alergi dan defisiensi zat besi. Pemeriksaan penunjang diperlukan untuk menentukan diagnosis, etiologi dan perawatan yang tepat. Pemberian suplemen pengganti zat besi dapat membantu mengurangi sensasi terbakar. Pemeriksaan lebih lanjut ke dokter spesialis kulit dan dokter spesialis penyakit dalam diperlukan sebagai tatalaksana lanjutan kondisi alergi dan defisiensi zat besi.

\section{DAFTAR PUSTAKA}

1. Regezi JA, Sciubba J, Jordan RCK. Oral Pathology: Clinical Pathologic Correlations Seventh Edition [Internet]. International Standard Book. 2017. Available from: www.elsevier.com/permissions.

2. Honarmand M, Farhad Mollashahi LF, Shirzaiy M, Sehhatpour M. Geographic tongue and associated risk factors among Iranian dental patients. Iran J Public Health. 2013;42(2):215-9.

3. Woo S-B. Oral Pathology. A Comprehensive Atlas and Text. Elsevier República de China. 2012.

4. Khan S. Benign Migratory Glossitis: Case Report and Literature Review. Biomed J Sci Tech Res. 2017;1(5):1548-50.

5. Ching V, Grushka M, Darling M, Su N. Increased prevalence of geographic tongue in burning mouth complaints: $A$ retrospective study. Oral Surg Oral Med Oral Pathol Oral Radiol. 2012;114(4):4448.

6. Cárcamo Fonfría A, Gómez-Vicente L, Pedraza MI, Cuadrado-Pérez ML, Guerrero Peral AL, Porta-Etessam J. Burning mouth syndrome: clinical description, pathophysiological approach, and a new therapeutic option. Neurol (English Ed [Internet]. 2017;32(4):219-23. Available from: http://dx.doi.org/10.1016/j.nrleng.2015.10. 005

7. Hamissi JH, Esfehani M, Hamissi Z. Case Report Treatment of Geographic Tongue Superimposing Fissured Tongue: A literature review with case report. Sch J Dent Sci. 2015;2(7):409-13.

8. Stoopler ET, France K, Ojeda D, Sollecito TP. Benign Migratory Glossitis. J Emerg Med [Internet]. 2018;54(1):e9-10. Available from: https://doi.org/10.1016/j.jemermed.2017.0 9.035

9. BW N, DD D, CM A, AC C. Oral and 
maxillofacial pathology. Elsevier Health Sciences. 2015.

10. Nikdel C. A Rare Case of Peanut Allergy Manifesting as Benign Migratory Glossitis. Open Access J Dent Sci. 2018;3(9):2-7.

11. Dafar A, Çevik-Aras H, Robledo-Sierra J, Mattsson U, Jontell M. Factors associated with geographic tongue and fissured tongue. Vol. 74, Acta Odontologica Scandinavica. 2016. 210-216 p.

12. Mangold AR, Torgerson RR, Rogers RS. Diseases of the tongue. Clin Dermatol. 2016;34(4):458-69.

13. SV DS, C DP, S Rao DR. Benign Migratory Glossitis- A Case of Hereditary Aetiology. IOSR J Dent Med Sci. 2016;15(08):10911.

14. Sicherer SH, Sampson HA. Food allergy: $A$ review and update on epidemiology, pathogenesis, diagnosis, prevention, and management. J Allergy Clin Immunol [Internet]. 2018;141(1):41-58. Available from:

https://doi.org/10.1016/j.jaci.2017.11.003

15. Ogueta C. I, Ramírez P. M, Jiménez O. C, Cifuentes M. M. Geographic Tongue: What a Dermatologist Should Know. Actas Dermosifiliogr. 2019;110(5):341-6.

16. Picciani $B$, Santos $V$ de $C$, Teixeira-Souza T, Izahias LM, Curty Á, Avelleira JC, et al. Investigation of the clinical features of geographic tongue: unveiling its relationship with oral psoriasis. Int $\mathrm{J}$ Dermatol. 2017;56(4):421-7.

17. Núñez Amin Dick T, Rocha Santos L, Carneiro S, Moore D, Pestana S, Laerte Boechat J, et al. Investigation of oral atopic diseases: Correlation between geographic tongue and fungiform papillary glossitis. J Stomatol Oral Maxillofac Surg. 2021;122(3):283-8.

18. Roth-Walter F, Pacios LF, Bianchini R, Jensen-Jarolim E. Linking iron-deficiency with allergy: Role of molecular allergens and the microbiome. Metallomics [Internet]. 2017;9(12):1676-92. Available from:

http://dx.doi.org/10.1039/C7MT00241F

19. Bhattacharya PT, Misra SR. Handbook of Famine, Starvation, and Nutrient Deprivation. Handb Famine, Starvation, Nutr Deprivation. 2017.

20. Lecor PA, Ndiaye ML, Guirassy ML, Sall H, Toure B. Burning Mouth Syndrome: Pathophysiology, Investigations and Management-A Review. Acta Sci Dent Sci. 2018;2(4):26-32.

21. Vellappally S. Burning mouth syndrome: $A$ review of the etiopathologic factors and management. $\mathrm{J}$ Contemp Dent $\mathrm{Pr}$.

\section{6;17(2):171-6.}

22. Khan S. Benign Migratory Glossitis: Case Report and Literature Review. Int J Clin Oral Maxillofac Surg. 2018;4(1):1.

23. Mirza D, Qureshi NR, Naqvi K. Benign migratory glossitis an unusual enigmatic lesion 2. Pakistan Oral Dent J. 2013;33(3):470-2.

24. Cawson R., Odell E. Cawson's essentials of oral pathology and oral medicine. Elsevier. London: Elsevier; 2017. 